\title{
Research on the Improvement of Lean Implementation performance Based on the Theory of Stakeholders
}

\author{
Xiaobing $\mathrm{Pei}^{1, \mathrm{a}}$, Shanglei Wang ${ }^{2, b}$ \\ ${ }^{1}$ School of Management, Tianjin University of Technology, Tianjin, China \\ ${ }^{2}$ School of Management, Tianjin University of Technology, Tianjin, China \\ a552403845@qq.com, b408534002@qq.com
}

Keywords: Lean implementation, lean production system, Performance improvement, Stakeholders theory.

\begin{abstract}
Lean production can make the enterprise gain advantage in the fierce competition. However, there have been slow progress and not significant or even negative effects and other phenomena in the process of implementing lean production. This phenomenon reflects the enterprise lean implementation performance level is not high. In this paper, by constructing the concept of lean implementation model and develop lean implement stakeholder classification management strategies to Improve lean implementation performance.
\end{abstract}

\section{Introduction}

Enterprises implement lean production can improve competitiveness, therefore the lean production has been widely used[1]. Enterprise to import the lean production is by building a lean production system, the purpose of eliminating the operation of all kinds of waste, lifting equipment and the employee's work efficiency, rapid response to market demand, and ultimately achieve a competitive market advantage. However, many enterprises to carry out the lean implementation effect is not ideal. Enterprises to implement the lean process, through a period of time trying to get some achievements, it is often difficult to implement lean production in the continuous operation of the enterprise, can appear even go against the trend. Describe only the system of content, on the implementation of the lean implementation from the aspect of theory research of the scientific method is the major breakthrough to realize lean implementation performance improvement.

\section{What is lean production?}

An operational definition of a lean production refers to the social - an integrated technical system, through the coordination of organizational structure, working characteristics, the suitability of personnel factors, technical change, continue to eliminate waste, to achieve the low cost, high efficiency, high quality production, the maximum to meet customer demand[2].This study thinks that lean production application is the theory in the concrete application in the process of enterprise production operation management . Its form mainly has two aspects: (1) The change of each dimension through the enterprise lean production system building. (2) The continuous operation of lean production system in the enterprise. The connection between the two by lean production system .Enterprises through the building form a lean production system, lean production system and lean production system as a carrier to lean production system.

\section{Case analysis of lean production system}

Lean implementation organization and management. WQ for electric vehicle production enterprises, the enterprises in the process of building lean production system in lean implementation theory, under the guidance of scientific lean management, actively participate in and guide the participants [3]. WQ electric depot in the introduction of lean production, lean production system in the process of building the top from the enterprise to the enterprise lean propulsion system at the grass-roots level, as shown in figure 1.Lean implementation of the leadership team to be responsible 
for implementing lean production concept spread, knowledge training and management, lean production system design and promote the adjustment, to carry out the implementation process of inspection, coordination, control, examination, etc, as well as the various functional departments of lean implementation of team management[4].

Overall planning implemented

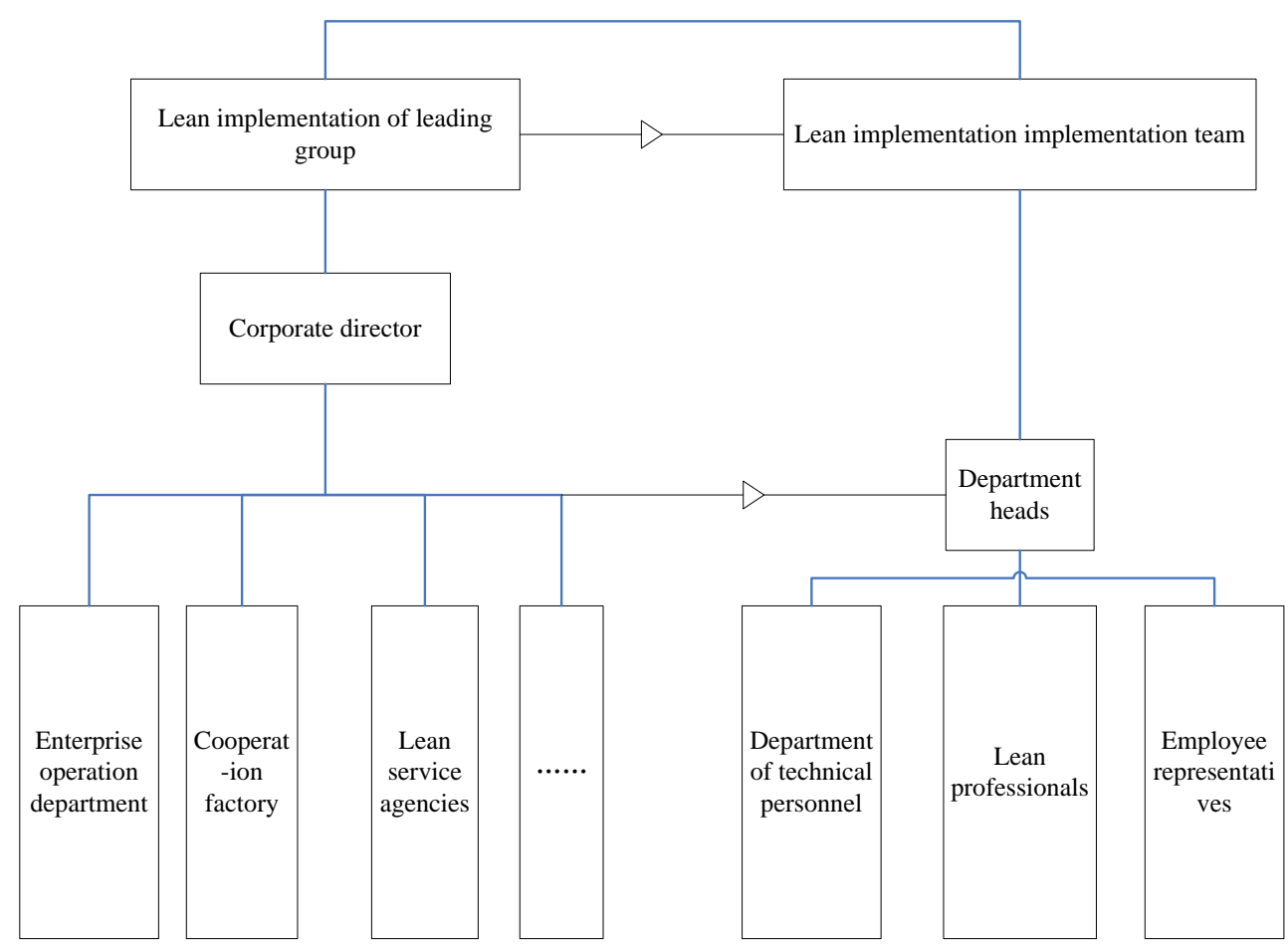

Fig. 1 The structure of lean implementation organization of WQ electric vehicle company

Lean implementation plan. Lean implementation of planning and design department and the content is more, so this part only in lean manufacturing, for example, the specific content see table 1.

Tab. 1 The specific content of lean implementation plan

\begin{tabular}{|c|c|c|c|c|}
\hline $\begin{array}{c}\text { Implementation o } \\
\text { the project }\end{array}$ & $\begin{array}{c}\text { Implementation of the } \\
\text { target }\end{array}$ & Content & Participants & Process \\
\hline $\begin{array}{l}\text { Quality control } \\
\text { system }\end{array}$ & $\begin{array}{l}\text { High level product } \\
\text { qualified rate of } \\
\text { banking }\end{array}$ & $\begin{array}{l}\text { Since, quality inspection } \\
\text { standards and standard } \\
\text { operation }\end{array}$ & $\begin{array}{l}\text { Processing } \\
\text { department, } \\
\text { department, } \\
\text { production } \\
\text { department }\end{array}$ & $\begin{array}{c}1 \text { defect investigation, found } \\
\text { the problem } \\
2 \text { traced back, eliminate the } \\
\text { defects and faults }\end{array}$ \\
\hline $\begin{array}{c}\text { Flexible } \\
\text { manufacturing } \\
\text { system }\end{array}$ & $\begin{array}{l}\text { Small batch, flow } \\
\text { production }\end{array}$ & $\begin{array}{c}\text { Facility layout, production } \\
\text { process standardization, } \\
\text { equalization, can work }\end{array}$ & $\begin{array}{l}\text { Processing } \\
\text { department, } \\
\text { production } \\
\text { department }\end{array}$ & $\begin{array}{c}1 \text { production process } \\
\text { standardization, facilities } \\
\text { layout improvement } \\
2 \text { pluripotent worker training, } \\
\text { equalization }\end{array}$ \\
\hline $\begin{array}{c}\text { Logistics } \\
\text { management } \\
\text { system }\end{array}$ & $\begin{array}{l}\text { On time, quality, } \\
\text { quantity supply }\end{array}$ & JIT, kanban, & $\begin{array}{l}\text { Material and } \\
\text { production }\end{array}$ & $\begin{array}{c}1 \text { logistics, logistics } \\
\text { equipment design } \\
2 \text { introducing kanban pull }\end{array}$ \\
\hline $\begin{array}{l}\text { Equipment } \\
\text { maintenance } \\
\text { system }\end{array}$ & $\begin{array}{l}\text { Maintain high } \\
\text { equipment } \\
\text { comprehensive } \\
\text { efficiency } \\
\end{array}$ & ТРM & $\begin{array}{c}\text { Production } \\
\text { department, } \\
\text { equipment } \\
\text { department }\end{array}$ & $\begin{array}{l}1 \text { the existing equipment } \\
\text { optimization improvement } \\
2 \quad \text { concept of TPM } \\
\text { comprehensive import }\end{array}$ \\
\hline $\begin{array}{c}\text { The control } \\
\text { system }\end{array}$ & $\begin{array}{c}\text { Building enterprise } 5 \mathrm{~s} \\
\text { control system }\end{array}$ & $5 \mathrm{~s}$ & $\begin{array}{c}\text { Each } \\
\text { department }\end{array}$ & $\begin{array}{c}15 \text { s activities in and between } \\
\text { example demonstration } \\
2 \text { the implementation of } 5 \mathrm{~s} \\
\text { activity } \\
3 \text { 5s results of curing }\end{array}$ \\
\hline
\end{tabular}




\section{Summary}

Lean implementation of WQ electric car manufacturing system whole optimization to promote changed the original production mode and management mode, eliminating the invalid labor and waste in the process of enterprise production and operation, effective utilization of resources, reduce costs, improve quality, with the least amount of inputs to achieve the purpose of the maximum output. Based on the process control of production management system, improve the flexibility of manufacturing system and shorten the reaction time, improve enterprise competitiveness, form suitable for the development of the enterprise itself with WQ characteristics lean manufacturing system and management system.

\section{References}

[1] Taylor A, Taylor M, McSweeney A. Towards greater understanding of success and survival of lean systems . International Journal of Production Research, 2013, 51(22): 6607-6630.

[2] Jayaram J, Das A, Nicolae M. Looking beyond the obvious: unraveling the Toyota production system . International Journal of Production Economics, 2010, 128(1): 280-291.

[3] Taj S, Morosan C. The impact of lean operations on the Chinese manufacturing performance . Journal of manufacturing technology management, 2011, 22(2): 223-240.

[4] Baker, P. 2002. “Why is Lean So Far off?” Works Management (55): 26-29.

[5] Blanchard D. Lean, Green and Low Cost. INDUSTRY WEEK-CLEVELAND OHIO-, 2007, 256(10): 37. 